\title{
GUATTERIA RICHARDII (ANNONACEAE) REDISCOVERED ALONG WITH TWO NEW SPECIES FROM FRENCH GUIANA
}

\author{
UWE SCHARF ${ }^{1}$, PAUL J.M. MAAS ${ }^{2} \&$ WILFRIED MORAWETZ ${ }^{1}$
}

\begin{abstract}
SUMMARY
For the first time, 140 years after the collection of the first specimen and 70 years after the description of Guatteria richardii R.E. Fr. from French Guiana, more specimens that are referable to this species were discovered during a taxonomic treatment for the Flora of the Guianas project, concerning Guatteria Ruiz \& Pav. (Annonaceae). In addition, G. intermedia and G. montis-trinitatis, two similar species - the first widely distributed and the second endemic to the Montagne de la Trinité in French Guiana, are described as new to science.
\end{abstract}

Key words: Annonaceae, Guatteria, tropical South America, Guayana Shield, Brazil, French Guiana, Suriname, taxonomy.

\section{INTRODUCTION}

Guatteria Ruiz \& Pav. is easily recognised by the combination of single-flowered, axillary inflorescences, a clearly visible articulation of the pedicel, apocarpous fruits with stipitate monocarps, and an impressed primary vein on the upper side of the leaf. Currently, 265 species (Chatrou et al., 2004) are recognised, with to date c. 40 occurring in the Guianas. The taxonomy of the genus is still based on the publications of R.E. Fries (1939, 1941, 1943, 1948a, b, c, 1949, 1950a, b, 1952, 1953, 1957a, b, 1960), whose work was based on the relatively few collections available at the time, a situation which in recent years has greatly improved.

Guatteria richardii R.E. Fr. was described in 1939, when just two specimens were available. The type collection was made by Louis Claude Richard somewhere along the River Kourou in French Guiana in the 1860s or 1870s, and is now stored in Paris (P) as a unicate. Mélinon 29 (P00115930) has been the second known specimen.

Despite the good accessibility of the River Kourou area, only one collection of $G$. richardii has been taken from there. Moreover, from neighbouring areas no collection was identified as G. richardii. The name does not appear regularly in regional floras and checklists (e.g., it does not appear in Steyermark et al., 1995; Boggan et al., 1997; Maas \& Maas-van de Kamer, 2002; but does appear in Hollowell et al., 2001). The Flora of the Guianas project, coordinated by the Utrecht branch of the National Herbarium of the Netherlands, provided the opportunity to revise this situation and to check the validity

1) Universität Leipzig, Institut für Botanik, Johannisallee 21, D-04103 Leipzig, Germany; e-mail: uscharf@uni-leipzig.de and morawetz@uni-leipzig.de

2) Nationaal Herbarium Nederland, Utrecht University branch, Heidelberglaan 2, 3584 CS Utrecht, The Netherlands; e-mail: p.j.m.maas@bio.uu.nl 
of this name because of its morphological position between G. ouregou (Aubl.) Dunal and a number of other species such as G. atra Sandwith, G. axilliflora (DC.) R.E. Fr., G. chrysopetala (Steud.) Miq., G. gracilipes R.E. Fr., G. ovalifolia R.E. Fr., G. poeppigiana Mart., G. punctata (Aubl.) Howard, G. sagotiana R.E. Fr., and G. wesselsboerii Jans.-Jac. These species are similar to each other and are possible synonyms (collectively referred to as $G$. punctata below). The large number of collections from the Guianas recently present in the Utrecht branch of the National Herbarium of the Netherlands (U) and on loan at the herbarium of the Leipzig University (LZ) were the base for improved understanding of formerly insufficiently known taxa within Guatteria, e.g., G. richardii. To the authors it was surprising that a reasonable number of collections appear to match this type collection, and thus providing a strong argument for not sinking $G$. richardii into another species. To this end an updated description based on a much enlarged number of new characters in conjunction with a detailed distribution map can now be provided.

Several new species of Guatteria for the Flora of the Guianas have recently been described (Scharf et al., 2005, 2006). In advance of a revision of Guatteria (Annonaceae) for the three Guianas, two further new species, G. intermedia and G. montis-trinitatis are described herein. Diagnostic characters of the new species are listed below the respective descriptions and in Table 1. Measurements of the pedicel are the sum of both the lower and upper part, i.e. the 'peduncle' and the 'pedicel s.str.' 1 . Inflorescences in Guatteria are axillary, and are generally reduced to a single flower. In our descriptions these are referred to as 'flowers'. The presence of more than one flower in a leaf axil indicates development of inflorescences from accessory (auxiliary) buds (see Fries, 1919; Weberling \& Hoppe, 1996).

Coordinates, if not on the herbarium sheet itself, were inferred from literature (Hoff \& Cremers, 1996), maps (see list of references) as well as from sources on the internet (Geonames, Falling Rain).

\section{Guatteria richardii R.E. Fr. (1939) 440 - Fig. 1; Map 1}

Type: Richard s.n. (holo P), French Guiana, Kourou R. (in ripis fluvii Kourou).

Tree, 3-8 m tall, $5 \mathrm{~cm}$ diam.; young twigs densely covered with erect, brown, curly hairs. Leaves: petiole 5 by $2-3 \mathrm{~mm}$; lamina narrowly elliptic, $10-23$ by $4-7 \mathrm{~cm}$, chartaceous, dull, greyish above, greyish to greenish brown below, very densely covered with appressed, brown hairs, but very soon glabrous above, densely covered with erect, light reddish brown, curly hairs below, not so dense as to hide the epidermis from view, base acute, apex acuminate (acumen 10-15 mm long), primary vein with a row of long, erect, brown, curly hairs above, persisting or later glabrous, rounded, densely covered with long, erect, brown hairs below, secondary veins flat above, 10-15 on either side of primary vein, angles of secondary veins with primary vein $50-60^{\circ}$,

1) Inflorescence: according to Chatrou (1998), the inflorescences of all Annonaceae can be considered as terminal. Apparently axillary inflorescences in genera such as Guatteria, Klarobelia, and Pseudomalmea consist of a short shoot, developing primarily from a leaf-axillary position, subtending a terminal pedicel with flower. The distinction between these two structures is in most cases clear, demarcated by an articulation. The short shoot bears a variable number of bracts which in occasional specimens are larger and leaf-like in appearance. 


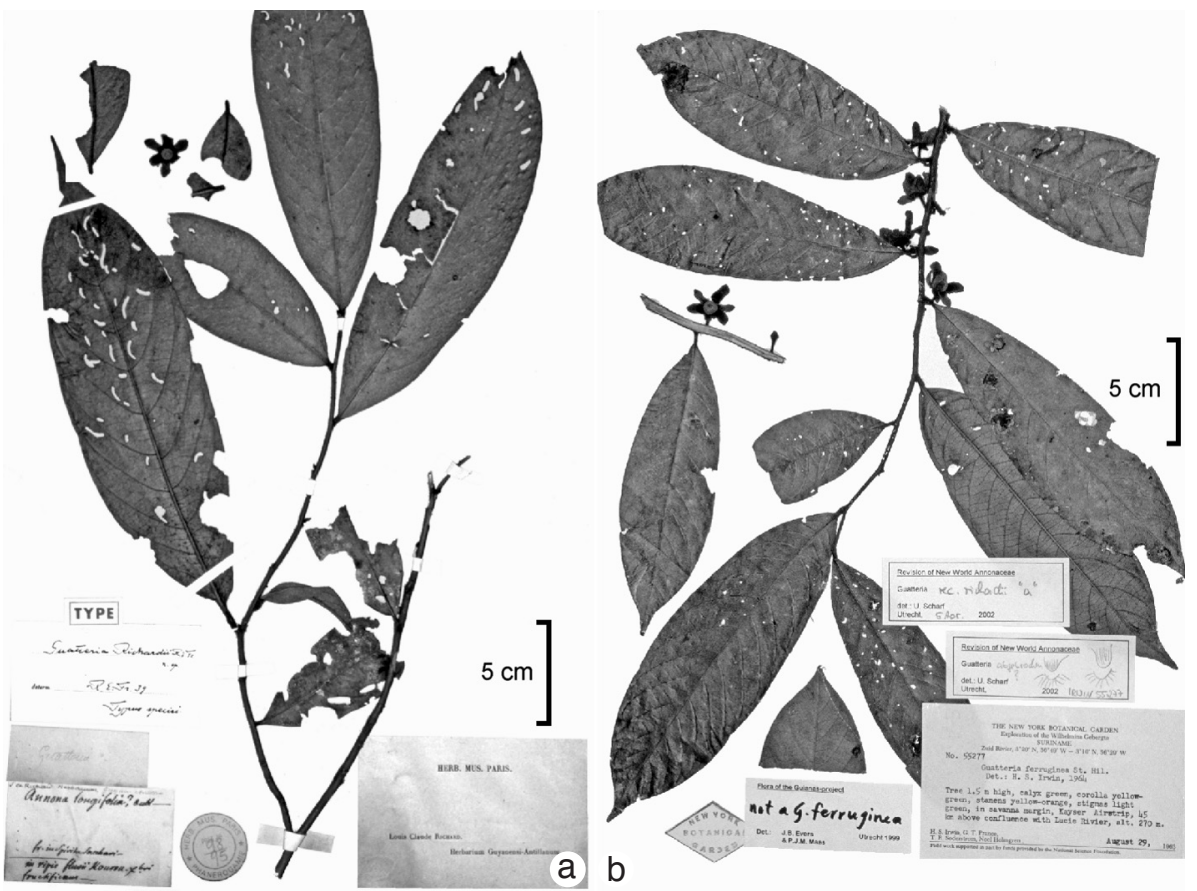

Fig. 1. Guatteria richardii R.E. Fr. Flowering twigs (a. Richard s.n. (holo P); b. Irwin et al. 55277 $(\mathrm{NY})$ ).

loop-forming (thin loops) at angles of $70-90^{\circ}$, smallest distance between loops and margin c. $2 \mathrm{~mm}$. Flowers 1 in a leaf axil, bud slightly pointed, pedicels $13-23 \mathrm{~mm}$ long, densely covered with brown erect or intertwining hairs; sepals broadly triangular, 6-7 by 5-6 mm, outer side densely covered with long, curly, brown hairs, inner side glabrous, apically (tips) reflexed; petals yellow in vivo, outer petals narrowly elliptic, c. 10 by $5 \mathrm{~mm}$, both sides densely covered with intertwining, curly or erect brown hairs, inner petals ovate, 7-9 by $5 \mathrm{~mm}$ (immature), densely covered with incurved brown hairs, inner side at the base glabrous; stamens pale orange-brown in sicco, 150-170, 1.5-1.75 mm long, connective shield umbonate, papillate; carpels 50-60, dark brown with some silvery hairs between the stigmas in sicco. Monocarps 20-27, maturing black in vivo, immature monocarps blackish to reddish brown in sicco, ellipsoid, c. 8 by $5 \mathrm{~mm}$, glabrous, except for a few hairs at the apex, apiculate, stipes $10-15 \mathrm{~mm}$ long, with few hairs. Seeds reddish brown, surface covered with little, shallow grooves and shiny, c. 7 by $5 \mathrm{~mm}$.

Distribution - French Guiana: Sinnamary; Suriname: Wilhelmina Mountains, Kayser Mountains.

Habitat \& Ecology - Primary forest, secondary vegetation, riparian forest, inundated forest. At elevations of 30-250 m.

Phenology - Flowering: September to November; fruiting: immature fruits from November on. 
Notes - 1. Cowan 38187 from adjacent Brazil (Amapá), incorrectly named 'G. ferruginea A. St.-Hil. forma' actually belongs to G. richardii. It deviates in its leaves that are relatively large (22-30 by $7-10 \mathrm{~cm}$, not included in the above description). The real G. ferruginea A. St.-Hil. occurs much further South and is cauliflorous. The type was collected in the Brazilian state of São Paulo (c. $20^{\circ} 40^{\prime}$ S, $49^{\circ} 20-50^{\prime}$ W).

2. For a long time Mélinon 29 was filed with Richard s.n. = type of G. richardii R.E. Fr. which caused some confusion. Fries (1939) already stumbled over that situation and concluded that the small twig and the loose flowers in the pocket seemed to belong to G. richardii and the fruiting twig belonged to another species namely G. chrysopetala (Steud.) Miq. (which is now included in G. punctata (Aubl.) Howard).

The authors of this article found in the folder of Richard s.n. just one sheet of Mélinon 29 where Fries had labelled the loose flowers in the pocket as "G. richardii" as well as the small twig on the sheet. Three premature leaves and some crushed flower bud fragments (Fries: "ein kleiner Zweig und lose Blüten") prevented a final conclusion from being drawn. Judging from the indument the material belongs to G. intermedia. This collection is catalogued in P under P00115930.

The fruiting twig Fries refers to is now no longer present in this folder. It is likely that Fries split the collection based on his revision because another "Mélinon 29" is present in P but listed under the number P00115951. This sheet bears a revision slip written by Fries in 1939 and his determination as G. chrysopetala. On this sheet three leaves (in fragments) and a fruiting pedicel still containing one monocarp are present. This collection now belongs to G. punctata.

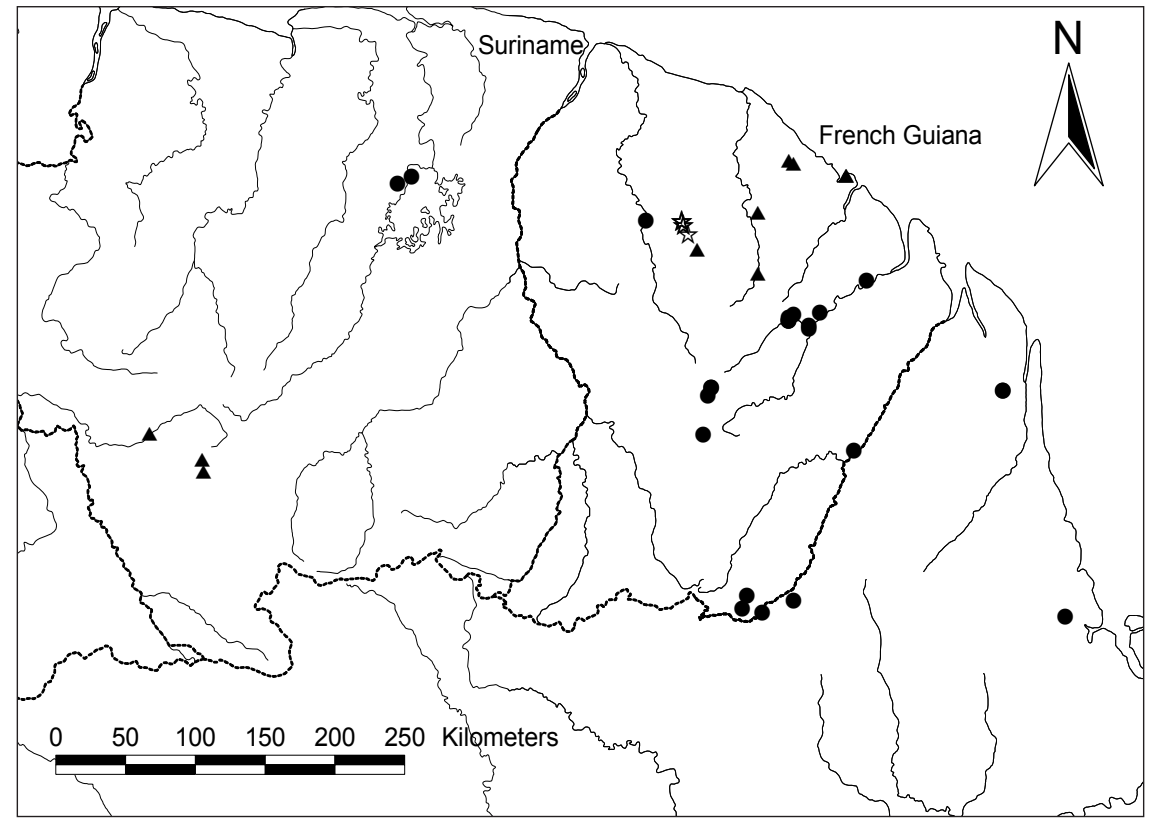

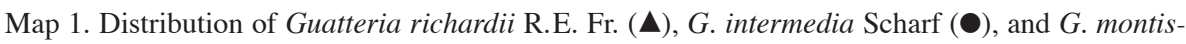
trinitatis Scharf (它) in the Guianas. 
The third sheet belonging to the same material but probably not seen by Fries in 1939 is a Mélinon s.n., also stored in P, but with the number P00115919. Obviously this sheet is derived from the same collection as number P00115951 and thus also belongs to Mélinon 29. It contains (in much better condition than P00115951) two fruiting twigs, bearing in total three leaves and two fruiting pedicels with monocarps and a number of loose monocarps in a pocket. Therefore determination was possible and P00115919 has now also been labelled as "G. punctata".

In conclusion, Mélinon 29 consists of at least three sheets, originally derived from a mixed collection. Fries (1939) already recognised them as a mixed collection. He probably did split the specimens of G. chrysopetala (syn. to G. punctata and now stored in P with the numbers P00115951 and P00115919) from the collection labelled as Richard s.n. (= type of G. richardii) but left behind the sheet now numbered P00115930 because he thought it belonged to G. richardii. The last remaining sheet of Mélinon 29 has now been removed from the folder of Richard s.n. because this material is most likely to represent the species $G$. intermedia. This poorly preserved specimen is currently stored in $\mathrm{P}$ with the number P00115930.

Specimens (12 collections) examined:

BRAZIL: Amapá. Rio Amapari, slopes of Curuca Ore Body, Cowan 38187 (NY, S); Municipio de Mazagão, Mori \& Cardoso 17424 (U).

French GuIANA: basin of Sinnamary R., Saut Coumarou, Bordenave 406 (CAY, U); Kourou, Cremers 9340 (CAY); basin of Sinnamary R., De Granville et al. 11238 (CAY, U), De Granville et al. 11324 (CAY); basin of Sinnamary R., Saut du Péril, Hoff 7700 (CAY, U); Cayenne, Leprieur s.n. 1838 p.p. (B), Leprieur s.n. 1840 p.p. (NY).

SURINAME: Kayser Mts., 18 km SW of Kayser airstrip, Mori \& Bolten 8627 (NY, US); Wilhelmina Mts., Zuid Rivier, Irwin et al. 55277 (F, NY, P, US), Irwin et al. 55715 (G, NY, P, RB, US).

\section{Guatteria intermedia Scharf, spec. nov. - Fig. 2; Map 1}

G. ouregou (Aubl.) Dunal affinis sed ramulis novellis pedicellisque pilis incurvis vel appressis (versus erectis) obtectis, foliorum costa subtus indumento denso pilis incurvis ornata et sepalis monocarpiisque minoribus differt. - Typus: Oldeman B.4125 (holo CAY; iso NY (not seen), P), French Guiana, Saül, Crique Cochon, 3³7' N, 53 12' W, 21 Oct. 1971.

Tree, 2-7 m tall, up to $15 \mathrm{~cm}$ diam.; young twigs densely covered with incurved, brown hairs, persisting for a shorter time than a growing period. Leaves: petiole $3-6(-10)$ by 1-2 $\mathrm{mm}$; lamina narrowly elliptic to narrowly obovate, $10-23$ by $4-7.5 \mathrm{~cm}$, chartaceous, mostly dull lead-coloured above, rarely with a pinch of olive or brown, greyish brown to pale greyish brown or reddish brown below, sparsely covered with appressed, long hairs, but very soon glabrous above, densely covered with appressed, pale brown, straight, long-persistent hairs below, primary vein with a dense row of incurved hairs above, densely covered with appressed long hairs below, base acute, apex acuminate (acumen 10-20 mm long), secondary veins distinct, flat to slightly raised above, 10-12 on either side of primary vein, angle of secondary veins with primary vein $45-60^{\circ}$, indistinctly loop-forming at almost right angles, smallest distance between loops and margin 1.5-3 mm. Flowers 1 (or 2) in a leaf axil; pedicels 10-20 mm long, densely covered with incurved hairs; sepals broadly ovate to broadly triangular, 4-5 by 5-7 mm, apex reflexed, outer side densely covered with appressed hairs, inner side, except for 


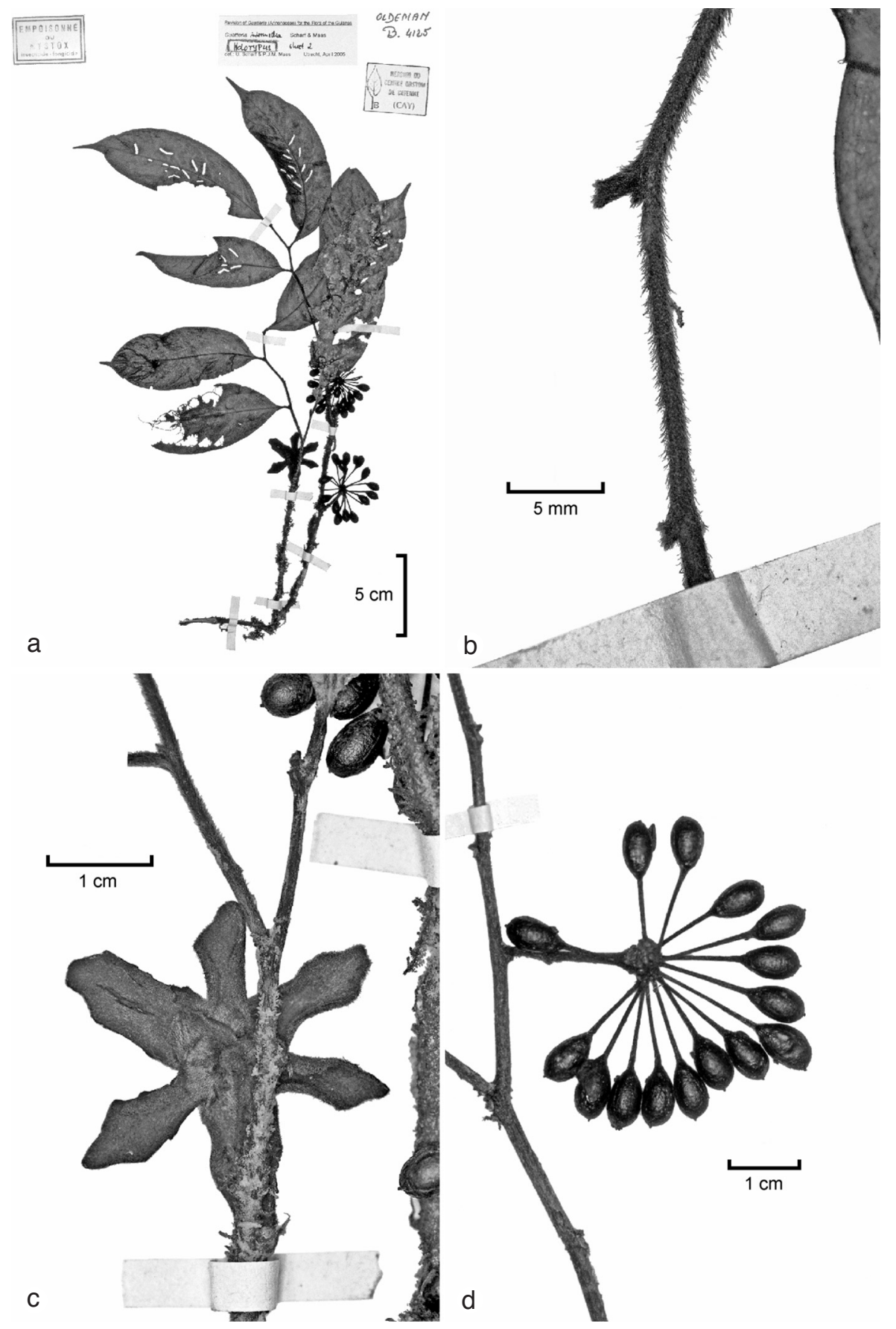

Fig. 2. Guatteria intermedia Scharf. a. Twig with flowers and fruits; b. incurved hairs on young twigs; c. flower, exposing pedicel, sepals, and outer side of the petals; d. fruits (all Oldeman B.4125 (CAY)). 
the apex, glabrous; petals greenish yellow to yellow in vivo, narrowly oblong-elliptic, outer petals $14-17$ by $5-6 \mathrm{~mm}$, inner petals $17-20$ by $7-10 \mathrm{~mm}$, outer side densely covered with appressed, rusty brown, curly hairs; stamens yellow to orange-brown, 180-220, 1.5-2 mm long, connective shield umbonate, densely papillate, rarely densely hairy; carpels 40-60, shiny black, densely covered with erect, whitish or brownish hairs. Monocarps 20-30, green, maturing black in vivo, shiny black or blackish brown in sicco, ellipsoid, 7-9 by $5 \mathrm{~mm}$, glabrous, apiculate (apicula $<1 \mathrm{~mm}$ long), stipes 14-27 mm long, slender, glabrous or some occasional hairs present. Seeds shiny redbrown, ellipsoid, $6-7$ by $4-5 \mathrm{~mm}$, slightly pitted.

Distribution - French Guiana, NW Suriname, and adjacent Brazil (Amapá).

Habitat \& Ecology - In primary or secondary lowland forest, riparian vegetation, along creeks, on granite. At elevations from sea level up to $250 \mathrm{~m}$.

Phenology - Flowering: August to March; fruiting: February, October, and December.

Vernacular names - French Guiana: i-wi (Wayampi); mamayavé (Créole).

Etymology - This species is named 'intermedia', because it possesses character states of G. ouregou, G. richardii, and G. punctata.

Notes - 1. Guatteria intermedia is similar to G. ouregou, but differs from the latter by having incurved to appressed hairs (instead of erect) on young twigs and pedicels, a dense indument of incurved hairs on the lower side of the primary vein, and smaller sepals (see Table 1 ) and monocarps ( $7-9$ by 5 vs $8-13$ by $5-10 \mathrm{~mm}$ ). These character states overlap in part with G. punctata (leaves) and G. richardii (flowers), but the indument on young twigs consists of long (G. punctata: short), appressed to incurved (G. richardii and $G$. ouregou: erect) hairs.

2. Guatteria intermedia has a core distribution between $2^{\circ} 14^{\prime} \mathrm{N}, 52^{\circ} 12^{\prime} \mathrm{W}$ and $5^{\circ} 17^{\prime} \mathrm{N}, 53^{\circ} 37^{\prime} \mathrm{W}$ in French Guiana, extending into Brokopondo, NW Suriname. Van Andel 4657 and 4569 are the only collections representing this species in Suriname.

3. Irwin et al. 48341 from Amapá, Rio Oiapoque was incorrectly identified as G.ferruginea A. St.-Hil. This species occurs much further south and is cauliflorous. The type collection was made in the Brazilian state of São Paulo (c. $20^{\circ} 40^{\prime} \mathrm{S}, 49^{\circ} 20-50^{\prime} \mathrm{W}$ ).

4. Mélinon 29 (P00115930) had been filed with the type of G. richardii. See note 2 under $G$. richardii.

Paratypes (16 collections examined):

BRAZIL: Amapá. Oiapoque R., 2-5 km SW of mouth of Rio Ingarari, Irwin et al. 48341 (F, NY, S, US); Oiapoque R., Mt Tipac, 0-200 m, Irwin et al. 48667 (G, NY, U); idem, 200-250 m, Irwin et al. 48732 (NY, U, US); Mun. de Calçoene, Rabelo et al. 2992 (U).

FRENCH GuIANA: Mana R., Baboune Cr., Cremers et al. 7467 (BR, P, U); basin of Approuague R., Cr. Jean-Pierre, Cremers et al. 13572 (BR, CAY, U, US); Saül, Layon de la Cr. Limonade, De Granville B.4561 (U, P); Oyapock R., Camopi, between Saut Ouacarayou and Ilets Camopi, De Granville T.1088 (NY, U); Oyapock R., Trois Sauts, Grenand 632 (U); Camp des Nouragues, Arataye R., Larpin 598 (U); Arataye R., Camp Arataye, less than 100 m, Mori et al. 25705 (U); Approuague R., Ipoucin Cr., Oldeman B.2148 (CAY, P, U); Saül, Tracé Belvédère, Cr. Cochon, Oldeman B.4126 (CAY, P); Arataye R., Saut Pararé, Sabatier et al. 36 (CAY, U).

SURINAME: Brokopondo, Van Blommestijn Lake, Tonka Island, Van Andel 4657 (BBS, U); Brownsberg, AKP road km 4, Van Andel 4569 (BBS, U). 


\section{Guatteria montis-trinitatis Scharf, spec. nov. - Fig. 3; Map 1}

A Guatteria richardii R.E. Fr. cui affinis, lamina anguste ovata et coriacea, marginibus revolutis, pedicellis brevioribus, petalis latioribus, numero staminum majore, numero carpellorum minore et stipitibus brevioribus differt. - Typus: De Granville et al. 5947 (holo U; iso B, BR, CAY, G, NY, P, US), French Guiana, Montagne de la Trinité, 1984.

Tree, 2-12 m tall, 1.5-3 cm diam.; young twigs densely covered with erect, brown hairs. Leaves: petiole $2-5$ by $2-4 \mathrm{~mm}$; lamina narrowly ovate, (12-)17-27 by 4-7(-9) $\mathrm{cm}$, bearing the broadest part in the basal third of the leaf, coriaceous, slightly rough and dull on both sides, silvery grey above, very soon glabrous, greyish with erect, but curly, dark reddish brown hairs below, not so dense as to hide the epidermis from view, base obtuse, leaf margin revolute, apex acuminate (acumen 10-20 mm long); primary vein with a row of erect, long, brown hairs above, on old leaves glabrous, rounded to slightly keeled and densely covered with erect, long, brown hairs below; secondary veins distinct, slightly raised above, $10-15$ on either side of the primary vein, angle of secondary veins with primary vein $50-70^{\circ}$, loop-forming at angles of $80-100^{\circ}$, smallest distance between loops and margin 2-4 mm. Flowers $1-3(-4)$ in a leaf axil; pedicels $9-16 \mathrm{~mm}$ long, densely covered with brown, erect or intertwining hairs; sepals broadly triangular-ovate, $6-8$ by $5-7 \mathrm{~mm}$, outer side densely covered with semi-appressed hairs, inner side basal glabrous, apex reflexed; petals pale greenish yellow in vivo, in the open bud more rounded and completely covered by hairs, in mature flowers outer petals elliptic, $12-18$ by $8-12 \mathrm{~mm}$, inner petals c. 26 by $14 \mathrm{~mm}$ (note 2), both sides densely covered with long, semi-appressed, rusty brown, curly hairs, inner side at the base glabrous; stamens pale yellow-orange in vivo, creamy to brownish in

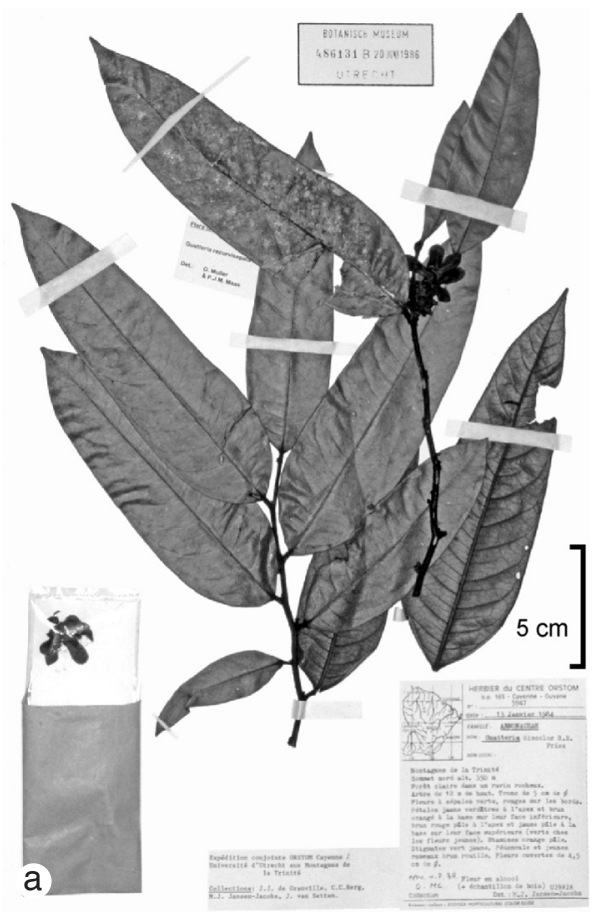

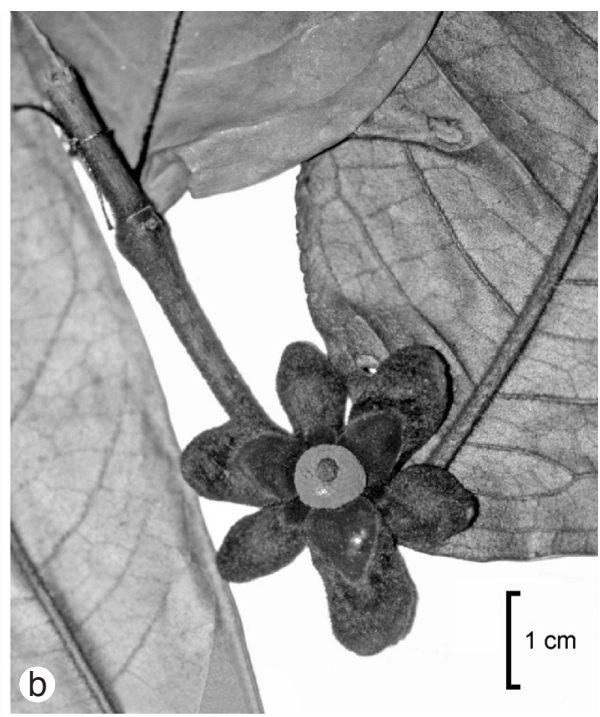

Fig. 3. Guatteria montis-trinitatis Scharf. a. Flowering twig; b. flower (a. De Granville 5947 (holo U); b. De Granville 6448 (S)). 
sicco, c. 200, c. $1.5 \mathrm{~mm}$ long, connective shield umbonate, papillate; carpels 20-35, pale yellowish green in vivo, black in sicco. Monocarps 15-25 (only incomplete infructescence seen), black in sicco, ellipsoid, c. 6 by $4 \mathrm{~mm}$, apiculate, stipes c. $7 \mathrm{~mm}$ long. Seeds not seen.

Distribution - French Guiana: Montagne de la Trinité.

Habitat \& Ecology - In high forest, in forest understorey, on hill top or slopes, on well-drained soils, on granite bedrock. At elevations of $280-500 \mathrm{~m}$.

Phenology - Flowering: January and February, fruiting: immature fruits from February on.

Etymology - This species was named after the Montagne de la Trinité in French Guiana where it was found.

Notes - 1. Guatteria montis-trinitatis differs from G. richardii (measurements in brackets) by its narrowly ovate and coriaceous (vs elliptic and chartaceous) leaves with revolute margins (vs not so), pedicels, which are 9-16 mm (vs 13-23 mm) long and densely covered with erect to intertwining reddish brown hairs, outer petals $12-18$ by $8-12 \mathrm{~mm}$ (vs 10 by $5 \mathrm{~mm}$ ), inner petals c. 26 by $14 \mathrm{~mm}$ (vs $7-9$ by $5 \mathrm{~mm}$ ), stamens c. 200 (vs 150-170), carpels $20-35$ (vs 50-60), stipes c. $7 \mathrm{~mm}$ (vs 10-15 mm) long, and the higher elevation of $280-500 \mathrm{~m}$, where it was found (vs $30-250 \mathrm{~m}$ ).

2. Measurements of the petals were taken from probably mature flowers pickled in spirit (De Granville et al. 5947).

Paratypes ( 5 collections examined):

French GuiAnA: Montagne de la Trinité, De Granville et al. 5942 (U), 6167 (B, CAY, G, NY, P, U, US), 6248 (CAY, U), 6448 (AAU, BR, CAY, G, P, S, U), 13456 (CAY, U).

\section{DISCUSSION AND TABLE}

Morphologically, G. richardii, G. intermedia, and G. montis-trinitatis are similar to G. punctata and G. ouregou. The erect hairs on the lower side of the leaf and the indument of curly hairs on sepals and petals are unique characters for G. richardii and G. montis-trinitatis, while G. intermedia has incurved hairs on the twigs, leaves, and pedicels. Guatteria richardii, G. ouregou, and G. intermedia are lowland (below $250 \mathrm{~m}$ ) species with elliptic and chartaceous leaves while G. montis-trinitatis was found only at elevations above $280 \mathrm{~m}$ and bears narrowly ovate and coriaceous leaves. Only the wide-spread G. punctata covers the whole altitudinal range between sea level and $660 \mathrm{~m}$. Some additional diagnostic characters of the species mentioned are listed in Table 1.

\section{KEY TO THE SPECIES}

1a. Young twigs and pedicels totally to sparsely covered with erect hairs . . . . . 2

b. Young twigs and pedicels densely to sparsely covered with appressed or incurved

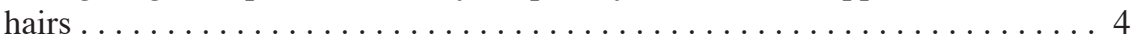

2a. Sepals $>8 \mathrm{~mm}$ long, appressed to contiguous, hairs on the lower side of the primary vein appressed, monocarps $8-13$ by $5-10 \mathrm{~mm} \ldots \ldots \ldots \ldots \ldots$. ouregou

b. Sepals $<8 \mathrm{~mm}$ long, reflexed, hairs on the lower side of the primary vein erect,

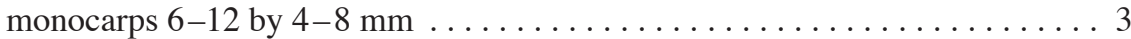

3a. Leaves narrowly elliptic, chartaceous, leaf base acute, leaf margins plain . ...... 


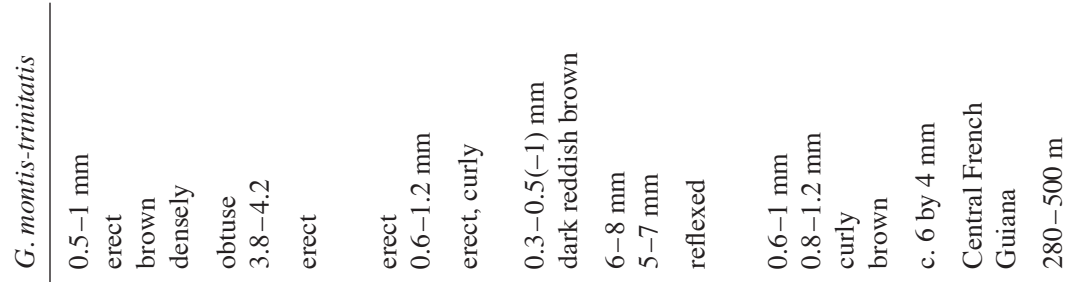

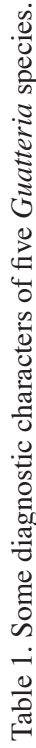

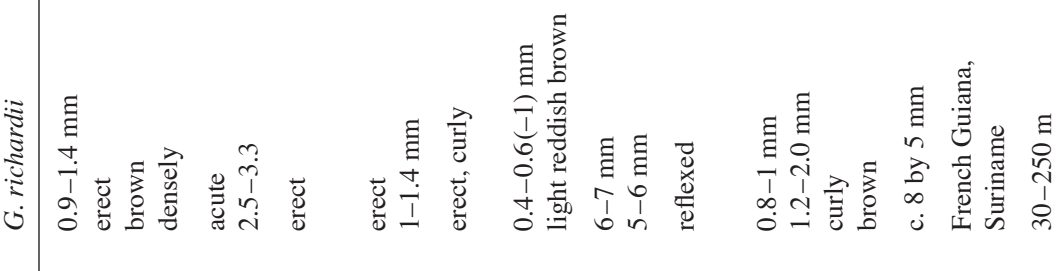

苟 者:

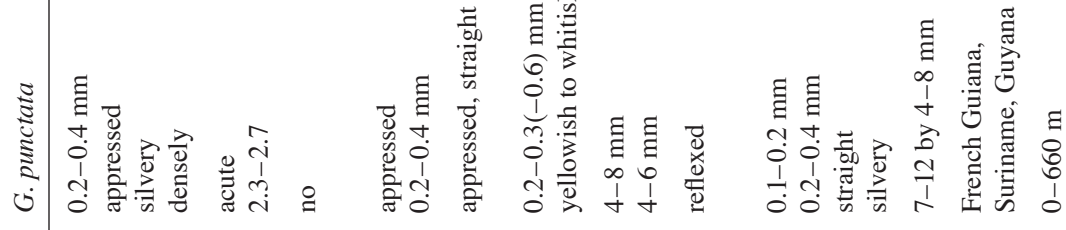
चี

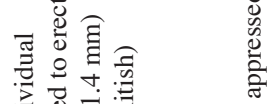

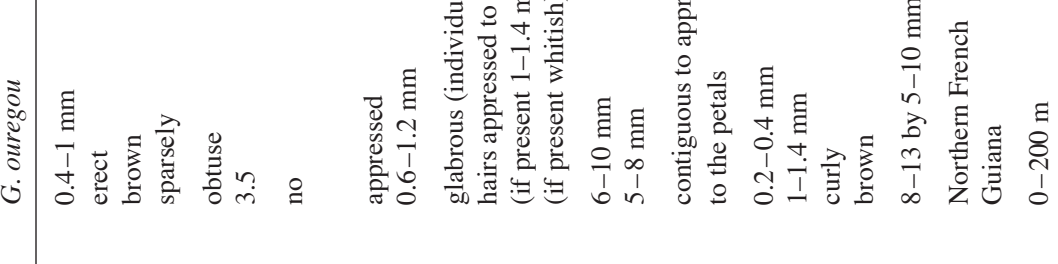

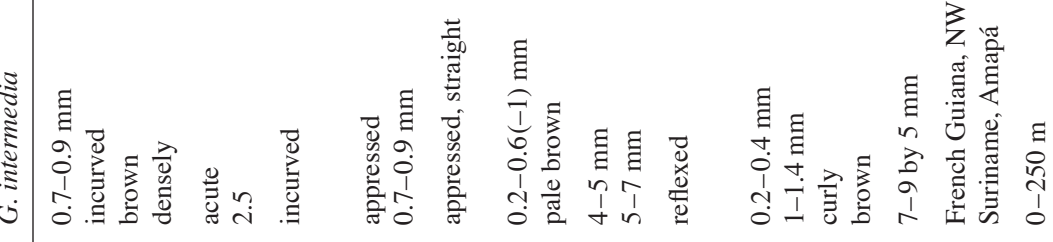

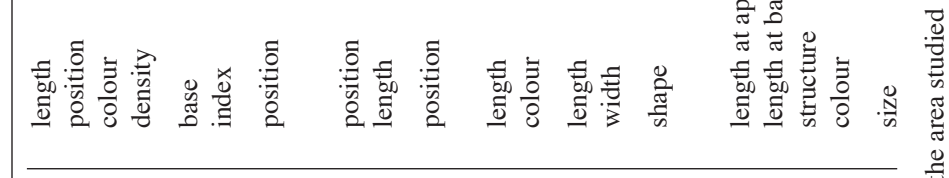

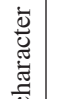

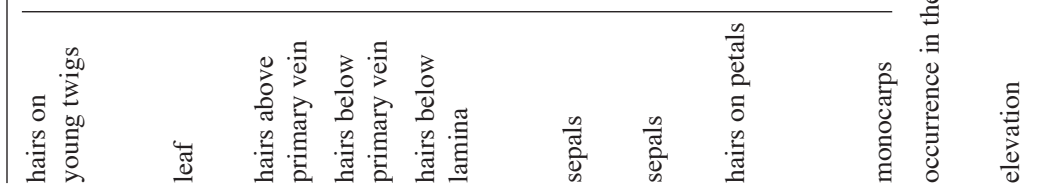


b. Leaves narrowly ovate, coriaceous, leaf base obtuse, leaf margins clearly revolute 3. G. montis-trinitatis

4a. Young twigs covered with incurved hairs $>0.7 \mathrm{~mm}$ long, upper side of primary vein covered with a dense row of incurved hairs, petals covered with brown and

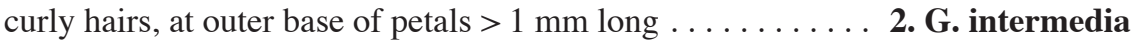

b. Young twigs covered with appressed hairs $<0.4 \mathrm{~mm}$ long, upper side of primary vein glabrous or very soon becoming glabrous, petals covered with silvery and appressed straight hairs, at outer base of petals $<0.4 \mathrm{~mm}$ long . . . . G. punctata

\section{ACKNOWLEDGEMENTS}

The work resulting in this publication was carried out in the context of the Flora of the Guianas project, in close cooperation with the Universität Leipzig, Germany, Herbarium LZ and the Nationaal Herbarium Nederland, Utrecht University branch (U). Latin diagnoses were corrected by Lubbert Y.Th. Westra. Roy H.J. Erkens helped a lot generating the distribution maps using ESRI data (NYBG, 2003). The photos were made by the author from herbarium sheets deposited or on loan in $U$ and LZ. The research was made possible by loans and duplicates sent from AAU, B, BBS, BM, BR, BRG, C, CAY, F, FDG, K, MO, NY, P, S, and US. The curators of these herbaria, and all colleagues involved are gratefully acknowledged.

\section{REFERENCES}

Boggan, J., V. Funk, C. Kelloff, M. Hoff, G. Cremers \& C. Feuillet. 1997. Checklist of the plants of the Guianas (Guyana, Surinam, French Guiana). 2nd edition. Biological Diversity of the Guianas Program, National Museum of Natural History, Smithsonian Institution, publication number 30, Washington.

Chatrou, L.W., H. Rainer \& P. J.M. Maas. 2004. Annonaceae. In: N. Smith, S. A. Mori, A. Henderson, D.W. Stevensen \& S.V. Heald (eds.), Flowering plants of the Neotropics: 18-20. Princeton, New Jersey, USA.

Fries, R.E. 1919. Studien über die Blütenstandsverhältnisse bei der Familie Anonaceae. Acta Horti Berg. 6: 23-35.

Fries, R.E. 1939. Revision der Arten einiger Annonaceen-Gattungen. V. Acta Horti Berg. 12: 289-577.

Fries, R.E. 1941. Neue amerikanische Annonaceen. Acta Horti Berg. 13: 103-116.

Fries, R.E. 1943. Einige Gesichtspunkte zur systematischen Gruppierung der amerikanischen Annonaceen-Gattungen. Ark. Bot. 30A, 8: 1-31.

Fries, R.E. 1948a. Contributions to the Flora of Tropical America. XLVII. Annonaceae new to British Guiana. Kew Bull. 1948: 229-235.

Fries, R.E. 1948b. New or noteworthy Annonaceae from tropical America. Kongl. Svenska Vetensk. Acad. Handl. ser. 3, 24, 10: 3-12.

Fries, R.E. 1948c. Annonaceae. In: B. Maguire et al., Plant explorations in Guiana in 1944, chiefly to the Tafelberg and the Kaieteur Plateau. VI. Bull. Torrey Bot. Club 75: 640-642.

Fries, R.E. 1949. Sobre la caulifloría en la familia de las Anonáceas. Lilloa 16: 251-261.

Fries, R.E. 1950a. Contributions to the knowledge of the Annonaceae in northern South America. Ark. Bot. n.s. 1, 6: 329-347.

Fries, R.E. 1950b. Three new species of Annonaceae from northern South America. Ark. Bot. n.s. 1, 11: 445-451.

Fries, R.E. 1952. Annonaceae. In: R.S. Cowan et al., Plant explorations of G. Wilson-Browne, S.J., in British Guiana. I. Kanuku Mountains. Brittonia 7: 395-396.

Fries, R.E. 1953. Contributions to the Flora of Tropical America. LIV. New trees and shrubs from British Guiana. Kew Bull. 1952: 255-257.

Fries, R.E. 1957a. Annonaceae. In: R.S. Cowan et al., New species and new records of plants in Guiana. Brittonia 8: 236-237. 
Fries, R.E. 1957b. Annonaceae. In: B. Maguire, J.J. Wurdack et al., The botany of the Guayana Highland. Part II. Mem. New York Bot. Gard. 9: 325-331.

Fries, R.E. 1960. Annonaceae. In: B. Maguire, J.J. Wurdack et al., The botany of the Guayana Highland. Part IV. Mem. New York Bot. Gard. 10: 22-23.

Hoff, M. \& Cremers, G. 1996. Index des noms de lieux des recoltes botaniques en Guyane française. Studies on the Flora of the Guianas no 77. Herbier du Centre ORSTOM de Cayenne, France.

Hollowell, T., P. Berry, V. Funk \& C. Kelloff. 2001. Preliminary checklist of the plants of the Guiana shield. Volume 1: Acanthaceae - Lythraceae. Biological Diversity of the Guianas Program, National Museum of Natural History, Smithsonian Institution, publication number 57, Washington.

Maas, P.J.M. \& H. Maas-van de Kamer. 2002. Annonaceae (Custard-apple family). In: S.A. Mori, G. Cremers, C.A. Gracie, J.-J. de Granville, S.V. Heald, M. Hoff \& J.D. Mitchell (eds.), Guide to the vascular plants of Central French Guiana. Part 2. Dicotyledons. Mem. New York Bot. Gard. 76, 2: 53-67.

The New York Botanical Garden. 2003. A digital basemap of the Americas for mapping and analyzing plant distributions. CD-ROM.

Scharf, U., P.J.M. Maas \& W. Morawetz. 2005. Five new species of Guatteria (Annonaceae) from the Pakaraima Mountains, Guyana. Blumea 50: 563-573.

Scharf, U., P.J.M. Maas \& W. Morawetz. 2006. Five new species of Guatteria (Annonaceae) from French Guiana, Guyana, and Suriname. Blumea 51: 117-130.

Steyermark, J., P.J.M. Maas, P.E. Berry, D.M. Johnson, N.A. Murray \& H. Rainer. 1995. Annonaceae. In: P.E. Berry, B.K. Holst \& K. Yatskievych (eds.), Flora of the Venezuelan Guayana 2: 413-469. Missouri Botanical Garden, St. Louis.

Weberling, F. \& J.R. Hoppe. 1996. Comparative morphological evaluation of inflorescence characters in Annonaceae. In: W. Morawetz \& H. Winkler (eds.), Biosystematics and Ecology 10: 29-53. Österreichische Akademie der Wissenschaften, Wien.

MAPS:

An international travel map of Surinam. Nr. 705. Scale $1: 750,000$. International travel maps, ITMB Publishing, Vancouver, Canada, 1998.

Guyane. Carte touristique au $1:$ 500,000. No. 3615. Institut Géographique National Paris, 1995.

INTERNET:

Geonames Query Home Page. http://gnswww.nga.mil/geonames/GNS/index.jsp

Falling Rain Genomics, Inc., World Index. http://www.fallingrain.com/world/

\section{IDENTIFICATION LIST}

The abbreviations after the collectors' numbers refer to the following taxa:

Guatteria in = intermedia

$\mathrm{mt}=$ montis-trinitatis

$\mathrm{ri}=$ richardii

Barrier et al. 2809: in - Bordenave 406: ri.

Cowan 38187: ri - Cremers et al. 7467: in; 9340: ri; 13572: in.

De Granville et al. 644: in; 4854: mt; 5942: mt; 5947: mt; 6167: mt; 6248: mt; 6448: mt; 11238: ri; 11324: ri; 13456: mt; B4561: in; T.1088: in; T.1151: in.

Grenand 632: in.

Hoff 7700: ri.

Irwin et al. 48341: in; 48667: in; 48732: in; 55277: ri; 55715: ri.

Larpin 598: in - Leprieur s.n. 1838: ri; s.n. 1840: ri.

Martin s.n.: in - Mori \& Bolten 8627: ri - Mori \& Cardoso 17424: ri - Mori et al. 25705: in.

Oldeman B.2148: in; B.4125: in; B.4126: in.

Prévost et al. 967: in; 2781: in.

Rabelo et al. 2992: in - Richard s.n.: ri - Riéra \& Sabatier 1342: in.

Sabatier et al. 36: in.

Van Andel 4569: in; 4657: in - Villiers et al. 4452: in. 